\title{
Idiopathic versus Provoked Renal Infarction: Characteristics and Long-Term Follow-Up of a Cohort of Patients in a Tertiary Hospital
}

\author{
Alejandra García-García ${ }^{a} \quad$ Pablo Demelo-Rodríguez ${ }^{a-c} \quad$ Lucia Ordieres-Ortega ${ }^{a}$ \\ Eva Cervilla-Muñoz ${ }^{a}$ Irene García-Fernández-Bravo ${ }^{a}$ Maria Dolores Pulfera \\ Ana López-Aparicio $^{a} \quad$ Francisco Galeano-Valle ${ }^{a-c}$ Jorge del Toro-Cervera ${ }^{a-c}$ \\ aThrombosis Unit, Department of Internal Medicine, Hospital General Universitario \\ Gregorio Marañón, Madrid, Spain; bSchool of Medicine, Universidad Complutense de \\ Madrid, Madrid, Spain; ' Instituto de Investigación Sanitaria Gregorio Marañón, Madrid, \\ Spain
}

\section{Keywords}

Renal infarction · Atrial fibrillation · Anticoagulation · Thrombophilia

\begin{abstract}
Background: There is limited evidence on the etiology and outcomes of renal infarction. A provoking factor is identified only in one- to two-thirds of patients. Methods: This is a retrospective observational study. The clinical characteristics and outcomes of patients with acute renal infarction were studied; the sample was divided into two groups according to the presence of at least one provoking factor at the time of diagnosis (atrial fibrillation, flutter, major thrombophilia, or renal artery malformations). Results: The study comprised 59 patients with a mean age of $63( \pm 16.7)$ years and a follow-up period of $3.1( \pm 2.8)$ years. An identifiable provoking factor was found for $59.3 \%$ of the renal infarctions at the time of diagnosis, and atrial fibrillation was the most frequent one (in $49.2 \%$ of all patients). Renal impairment was found in $49.2 \%$ of the patients at diagnosis and in $50.8 \%$ of the patients 6 months after the event $(p=0.525)$. When compared with the idiopathic group, the patients with provoked infarction were older (69.8 vs. 57.9 years, $p=0.014$ ) and had a higher rate of recurrence of arterial thrombosis during follow-up ( $18.8 \mathrm{vs.} 0 \%, p=0.028)$, but there were no differences in the rest of the baseline characteristics or in mortality rates. Six patients (10.2\%) in the idiopathic group were diagnosed with atrial fibrillation during follow-up. Conclusions: Atrial fibrillation, both at di-
\end{abstract}

A. García-García and P. Demelo-Rodríguez contributed equally to this research article. 
Kidney
Blood Pressure

Research

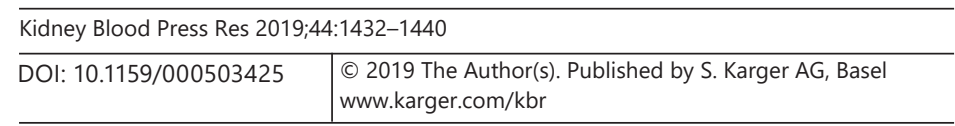

García-García et al.: Idiopathic versus Provoked Renal Infarction

agnosis and at follow-up, is the most common identifiable cause of renal infarction; however, a significant number of patients are idiopathic, and these are younger, but they have a similar burden of cardiovascular disease and a lower risk of arterial recurrence.

(c) 2019 The Author(s)

Published by S. Karger AG, Basel

\section{Introduction}

Renal infarction is an underdiagnosed pathology that arises as a sudden interruption of blood flow to the renal artery. The prevalence of renal infarction has been estimated from autopsy studies as 14 per 1,000 , but the incidence in clinical practice is probably lower, since many cases are not diagnosed, as suggested by other studies in which the incidence of renal infarction in emergency departments was only $0.007 \%$ [1-3].

Classically, it has been argued that the origin of renal infarction is usually cardioembolic, especially due to atrial fibrillation [4]. However, atrial fibrillation is present in only 18-64\% of patients according to different series. Other, less frequent causes include hypercoagulable states and structural damage to the renal artery, while in $30-60 \%$ of patients with renal infarction no provoking factor is identified [4-6].

The most frequent form of presentation is abdominal pain or flank pain, accompanied by low-grade fever, nausea, and vomiting, with frequent elevation of lactate dehydrogenase levels $[3,6,7]$. Given the lacking specificity of these symptoms, renal infarction is often confused with other diseases such as ureterorenal colic or pyelonephritis [8].

The diagnosis is established by imaging techniques, with contrast CT being the most widely used diagnostic method [3] (Fig. 1). Early diagnosis of this pathology is important in order to promptly initiate antithrombotic treatment and decrease the risk of renal functional loss.

The aim of the present study was to describe the presentation and long-term follow-up of a cohort of patients diagnosed with renal infarction, comparing the outcomes of the patients according to the presence or absence of a provoking factor.

\section{Methods}

A retrospective observational study was performed, including patients with a confirmed diagnosis of renal infarction in a third-level hospital of the Community of Madrid, Spain. The clinical records of 64 patients older than 18 years who were diagnosed with a renal infarction within a period of 10 years (2005-2015) were studied; 5 patients were excluded due to the absence of clinical data or loss to follow-up.

The epidemiological background of the patients was analyzed, including cardiovascular risk factors, the presence of arrhythmias (with greater attention with a diagnosis of atrial fibrillation or atrial flutter), structural heart disease, cerebrovascular disease, peripheral arterial disease, venous thromboembolism, cancer, and previous treatment.

The clinical manifestations, as well as complementary tests including imaging tests (abdominal CT, Doppler ultrasound, arteriography, etc.) and laboratory tests including levels of creatine kinase, lactate dehydrogenase, and creatinine at diagnosis, were studied.

Data were collected on the patients' outcomes, including a subsequent diagnosis of arrhythmias or heart disease; a diagnosis of thrombophilia (that included antithrombin, homocysteine, proteins $\mathrm{C}$ and $\mathrm{S}$, antiphospholipid antibodies, factor V Leiden, and prothrombin mutation); creatinine levels at 6 months; bleeding; arterial or venous thrombotic recurrences; cardiovascular disease; and mortality of any cause. The glomerular filtration rate (GFR) was 


\section{Kidney \\ Blood Pressure \\ Research}

\begin{tabular}{l|l}
\hline Kidney Blood Press Res 2019;44:1432-1440 \\
\hline DOI: 10.1159/000503425 & $\begin{array}{l}\text { @ 2019 The Author(s). Published by S. Karger AG, Basel } \\
\text { www.karger.com/kbr }\end{array}$ \\
\hline
\end{tabular}

García-García et al.: Idiopathic versus Provoked Renal Infarction

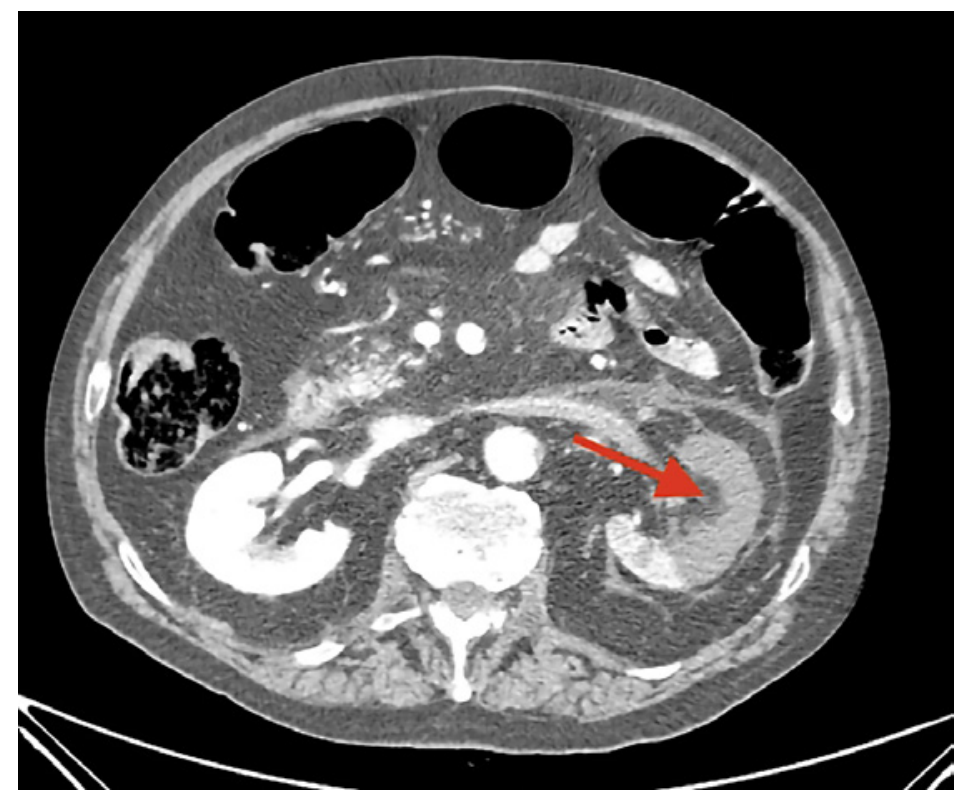

Fig. 1. Abdominal CT of a patient with acute renal infarction in the left kidney. Extensive areas of vascular hypoperfusion (red arrow) are evident in the left kidney.

estimated using the MDRD (Modification of Diet in Renal Diseases) equation. Renal impairment was defined as a GFR $<60 \mathrm{~mL} / \mathrm{min} / 1.73 \mathrm{~m}^{2}$.

Subsequently, the sample was divided into two cohorts depending on the presence or absence of a provoking factor for renal infarction at the time of diagnosis (atrial fibrillation, flutter, major thrombophilia, or renal artery malformations). An analysis of both subgroups was performed in terms of baseline characteristics and outcomes.

The qualitative variables are presented with a frequency distribution. The quantitative variables are presented as the mean and standard deviation in the case of a normal distribution or as the median and 25th and 75th percentiles in the case of a nonnormal distribution. The $\chi^{2}$ test was used for qualitative variables. The Student $t$ test and the Kruskal-Wallis test were used to compare means when the distribution of the variable was parametric and nonparametric, respectively. A $p$ value $<0.05$ was established as statistically significant. The statistical analysis was performed using the software SPSS version 19.

\section{Results}

The study comprised 59 patients diagnosed with renal infarction with a mean age of $63.03( \pm 16.7)$ years. The baseline characteristics and presentation forms of the patients with renal infarction are shown in Table 1 . An identifiable provoking factor was found in $59.3 \%$ of the patients, including atrial fibrillation $(49.2 \%$; 30 patients), renal artery malformation (6.8\%; 4 patients), and antiphospholipid syndrome (1.7\%; 1 patient). At the time of diagnosis of renal infarction, $30.5 \%$ of the patients were receiving anticoagulant therapy, all of them due to atrial fibrillation. Of these, 6 patients (33.3\%) received a low dose (understood as an INR below the range in patients with vitamin $\mathrm{K}$ antagonists or suboptimal doses in patients with low-molecular-weight heparins or other anticoagulants).

Renal impairment (GFR $<60 \mathrm{~mL} / \mathrm{min} / 1.73 \mathrm{~m}^{2}$ ) was found in $49.2 \%$ of the patients at diagnosis and in $50.8 \%$ of the patients 6 months after the event. This difference was not statistically significant $(p=0.525)$. During follow-up, $6.5 \%$ of the patients developed severe renal impairment (GFR $<30 \mathrm{~mL} / \mathrm{min} / 1.73 \mathrm{~m}^{2}$ ) as a consequence of renal infarction. 
Kidney

Blood Pressure

Research

Table 1. Baseline characteristics and presentation forms of the patients with renal infarction

\begin{tabular}{l|l}
\hline Kidney Blood Press Res 2019;44:1432-1440 \\
\hline DOI: 10.1159/000503425 & $\begin{array}{l}\text { ( ) 2019 The Author(s). Published by S. Karger AG, Basel } \\
\text { www.karger.com/kbr }\end{array}$ \\
\hline
\end{tabular}

García-García et al.: Idiopathic versus Provoked Renal Infarction

\begin{tabular}{|c|c|c|}
\hline & $n$ & $\%$ \\
\hline \multicolumn{3}{|l|}{ Medical background } \\
\hline Sex (male) & 35 & 59.3 \\
\hline \multicolumn{3}{|l|}{ Smoking } \\
\hline Active smoker & 36 & 61 \\
\hline Former smoker & 16 & 27.1 \\
\hline Nonsmoker & 7 & 11.9 \\
\hline Diabetes & 9 & 15.3 \\
\hline Arterial hypertension & 26 & 44.1 \\
\hline Treatment with statins & 25 & 42.9 \\
\hline Atrial fibrillation & 29 & 49.2 \\
\hline Known atrial fibrillation & 19 & 32.2 \\
\hline De novo atrial fibrillation & 10 & 16.9 \\
\hline Atrial flutter & 1 & 1.7 \\
\hline Other noncardioembolic arrhythmias & 4 & 6.8 \\
\hline Structural heart disease & 20 & 33.9 \\
\hline Ischemic heart disease & 7 & 11.9 \\
\hline Stroke/TIA & 13 & 22 \\
\hline Peripheral artery disease & 7 & 11.9 \\
\hline Venous thromboembolism & 2 & 3.4 \\
\hline Active cancer & 4 & 6.8 \\
\hline Anticoagulant therapy & 18 & 30.5 \\
\hline Properly anticoagulated & 12 & \\
\hline Not properly anticoagulated & 6 & \\
\hline \multicolumn{3}{|l|}{ Clinical presentation } \\
\hline Abdominal pain & 44 & 74.6 \\
\hline Back pain & 31 & 52.5 \\
\hline Nausea and/or vomiting & 27 & 45.8 \\
\hline Fever & 12 & 20.3 \\
\hline Urinary syndrome & 5 & 8.5 \\
\hline Hematuria & 24 & 40.7 \\
\hline \multicolumn{3}{|l|}{ Tests performed at diagnosis } \\
\hline Doppler ultrasound & 11 & 18.6 \\
\hline $\mathrm{CT}$ & 56 & 94.9 \\
\hline Angiography & 3 & 5.1 \\
\hline Angio-NMR & 3 & 5.1 \\
\hline \multicolumn{3}{|l|}{ ECG } \\
\hline Sinus rhythm & 22 & 37.3 \\
\hline Atrial fibrillation & 29 & 49.2 \\
\hline Atrial flutter & 1 & 1.7 \\
\hline Holter ECG & 10 & 16.9 \\
\hline Transthoracic echocardiogram & 43 & 72.9 \\
\hline Transesophageal echocardiogram & 7 & 11.9 \\
\hline Thrombus in left atrial appendage & 5 & 8.5 \\
\hline \multicolumn{3}{|l|}{ Presentation form } \\
\hline \multicolumn{3}{|l|}{ Affected kidney } \\
\hline Right & 23 & 39 \\
\hline Left & 28 & 47.5 \\
\hline Bilateral & 8 & 13.6 \\
\hline \multicolumn{3}{|l|}{ Infarction in other locations } \\
\hline Splenic & 9 & 15.3 \\
\hline Other & 3 & 5.1 \\
\hline Concomitant venous thrombosis & 1 & 1.7 \\
\hline Renal artery malformation at diagnosis & 4 & 6.8 \\
\hline
\end{tabular}

TIA, transient ischemic attack; NMR, nuclear magnetic resonance; ECG, electrocardiogram. 
Table 2. Treatment and outcomes of the patients with renal infarction

\begin{tabular}{|c|c|c|}
\hline & $n$ & $\%$ \\
\hline \multicolumn{3}{|l|}{ Treatment } \\
\hline Surgical thrombectomy & 1 & 1.7 \\
\hline Interventional thrombolysis & 0 & 0 \\
\hline Systemic fibrinolysis & 1 & 1.7 \\
\hline Antiplatelet therapy & 9 & 15.3 \\
\hline \multicolumn{3}{|l|}{ Long-term anticoagulation } \\
\hline Vitamin $\mathrm{K}$ antagonists & 44 & 74.5 \\
\hline LMWH & 13 & 22 \\
\hline Direct oral anticoagulants & 1 & 1.7 \\
\hline No treatment & 1 & 1.7 \\
\hline \multicolumn{3}{|l|}{ Follow-up } \\
\hline Atrial fibrillation & 6 & 10.2 \\
\hline Arterial recurrence & 7 & 11.9 \\
\hline Renal infarction & 3 & 5.1 \\
\hline Cerebrovascular disease & 2 & 3.3 \\
\hline Ischemic heart disease & 3 & 5.1 \\
\hline Venous recurrence & 2 & 3.3 \\
\hline Death & 9 & 15.3 \\
\hline Heart failure & 4 & \\
\hline Bleeding & 1 & \\
\hline Cerebrovascular disease & 1 & \\
\hline Other (noncardiovascular) & 3 & \\
\hline
\end{tabular}

The mean follow-up was $3.1( \pm 2.8)$ years. Seven recurrent episodes of arterial thrombosis were observed (11.9\%). Likewise, 2 episodes of venous thromboembolism were recorded (3.4\%). In addition, during follow-up, atrial fibrillation was diagnosed in another 6 patients $(10.2 \%)$ in the idiopathic group. Nine patients $(15.3 \%)$ died, the most frequent cause being heart failure (Table 2). The average survival rate at 5 years was $82.9 \%$. Thrombophilia testing, which was performed at the physician's discretion, showed normal results in 8 patients (61.5\%), hyperhomocysteinemia in 4 patients $(30.7 \%)$, and antiphospholipid syndrome in 1 patient $(7.6 \%)$.

When compared with the idiopathic group, the patients with provoked renal infarction were older ( 69.8 vs. 57.9 years, $p=0.014$ ), but no statistically significant differences were found in the rest of the baseline characteristics, including the presence of cardiovascular risk factors, heart disease, arterial disease, and the presentation of renal infarction (Table 3).

During follow-up, the incidence of arterial recurrence (arterial embolism, ischemic cardiopathy, or cerebrovascular disease) was higher among the patients with provoked renal infarction (18.8 vs. $0 \%, p=0.028)$. The incidence of venous thrombosis and mortality was similar in both groups ( 3 vs. $4.5 \%, p=0.76 ; 20.6$ vs. $8.7 \%, p=0.22$ ) (Table 3). There was also no difference in terms of survival.

\section{Discussion}

Our study found that atrial fibrillation is the most common identifiable risk factor for acute renal infarction, with a significant number of cases diagnosed during follow-up. Besides, patients with provoked renal infarction have a significantly higher risk of thrombotic recurrence. 
Table 3. Comparison between the patients with provoked and those with idiopathic renal infarction

\begin{tabular}{|c|c|c|c|}
\hline & $\begin{array}{l}\text { Provoked } \\
(n=35)\end{array}$ & $\begin{array}{l}\text { Idiopathic } \\
(n=24)\end{array}$ & $p$ value \\
\hline \multicolumn{4}{|l|}{ Baseline characteristics } \\
\hline Age at diagnosis, years & 69.9 & 57.9 & 0.014 \\
\hline \multicolumn{4}{|l|}{ Sex } \\
\hline Male & $57.1 \%$ & $62.5 \%$ & 0.681 \\
\hline Female & $42.9 \%$ & $37.5 \%$ & 0.681 \\
\hline \multicolumn{4}{|l|}{ Smoking } \\
\hline Smoker & $62.9 \%$ & $58.3 \%$ & 0.159 \\
\hline Former smoker & $17.1 \%$ & $4.3 \%$ & 0.159 \\
\hline Nonsmoker & $20 \%$ & $37.5 \%$ & 0.159 \\
\hline Arterial hypertension & $61.8 \%$ & $45.8 \%$ & 0.230 \\
\hline Diabetes & $20 \%$ & $8.3 \%$ & 0.221 \\
\hline Treatment with statins & $42.9 \%$ & $41.7 \%$ & 0.980 \\
\hline Structural heart disease & $40 \%$ & $25 \%$ & 0.232 \\
\hline Ischemic heart disease & $11.4 \%$ & $12.5 \%$ & 0.901 \\
\hline Stroke/TIA & $28.6 \%$ & $12.5 \%$ & 0.143 \\
\hline Peripheral artery disease & $14.3 \%$ & $8.3 \%$ & 0.487 \\
\hline Venous thromboembolism & $0 \%$ & $8.3 \%$ & 0.082 \\
\hline Active cancer & $5.7 \%$ & $8.3 \%$ & 0.694 \\
\hline \multicolumn{4}{|l|}{ Presentation form } \\
\hline Time to diagnosis, $\mathrm{h}$ & 36.76 & 60.41 & 0.153 \\
\hline Thrombus in left atrial appendage & $5.9 \%$ & $12.5 \%$ & 0.37 \\
\hline $\mathrm{LDH}$ at diagnosis, $\mathrm{U} / \mathrm{L}$ & $1,051.82$ & $1,174.83$ & 0.769 \\
\hline Creatinine at diagnosis, $\mathrm{mg} / \mathrm{dL}$ & 1.52 & 1.53 & 0.799 \\
\hline Creatinine peak, mg/dL & 1.83 & 1.87 & 0.670 \\
\hline $\mathrm{CK}$ at diagnosis, $\mathrm{U} / \mathrm{L}$ & 287.04 & $1,147.27$ & 0.939 \\
\hline \multicolumn{4}{|l|}{ Follow-up } \\
\hline Arterial recurrence ${ }^{1}$ & $18.8 \%$ & $0 \%$ & 0.028 \\
\hline Venous recurrence & $3 \%$ & $4.5 \%$ & 0.769 \\
\hline Death & $20.6 \%$ & $8.7 \%$ & 0.227 \\
\hline
\end{tabular}

TIA, transient ischemic attack; LDH, lactate dehydrogenase; CK, creatine kinase. ${ }^{1}$ Arterial recurrence includes arterial embolism, ischemic heart disease, and stroke.

According to conventional teaching, acute renal infarction should be suspected when a patient presents with the following triad: (1) persisting abdominal or loin pain; (2) elevated serum levels of lactate dehydrogenase and/or microscopic hematuria, and (3) a high risk of thromboembolic events [4]. However, a significant number of patients with acute renal infarction have a low risk of thrombosis. The data from the present study coincide with those of other studies and show that atrial fibrillation is the most common arrhythmia among patients with acute renal infarction. Nevertheless, the prevalence of atrial fibrillation in these patients presents a high variability according to the published series $[1,4-6]$. In our study, the rate of atrial fibrillation was $49.2 \%$ if we include both the patients with a history of atrial fibrillation and those with newly diagnosed atrial fibrillation. Besides, an additional $10 \%$ of the patients presented with atrial fibrillation during follow-up, suggesting that they could have had a previously underrecognized paroxysmal atrial fibrillation. According to these data, it seems justified to perform an exhaustive diagnostic study to rule out the presence of cardioembolic arrhythmias in patients with acute renal infarction not only at diagnosis but also during follow-up. 


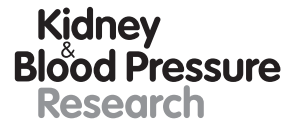

García-García et al.: Idiopathic versus Provoked Renal Infarction

Table 4. Review of the literature on renal infarction

\begin{tabular}{|c|c|c|c|c|c|c|c|}
\hline $\begin{array}{l}\text { First author } \\
\text { [Ref.] }\end{array}$ & $\begin{array}{l}\text { Patients, } \\
n\end{array}$ & $\begin{array}{l}\text { Age, } \\
\text { years }\end{array}$ & $\begin{array}{l}\text { Male, } \\
\%\end{array}$ & $\begin{array}{l}\text { Baseline } \\
\text { creatinine, } \\
\text { mg/dL }\end{array}$ & $\begin{array}{l}\text { Incidence of } \\
\text { acute kidney } \\
\text { injury, } n / N\end{array}$ & $\begin{array}{l}\text { Follow-up, } \\
\text { months }\end{array}$ & $\begin{array}{l}\text { Renal } \\
\text { loss, } \\
n / N\end{array}$ \\
\hline Lessman [14] & 17 & $58(41-73)$ & 76.5 & 6.6 & $11 / 17$ & 23.1 & $2 / 17$ \\
\hline Korzets [7] & 11 & $67.5(40-85)$ & 54.5 & $1.4 \pm 0.4$ & $3 / 11$ & 5.7 & $1 / 11$ \\
\hline Hazanov [15] & 44 & $69.5 \pm 12.6$ & 47.7 & $1.8 \pm 1.7$ & $15 / 38$ & 13.4 & $3 / 38$ \\
\hline Tsai [16] & 18 & 44.7 & 66.7 & ND & $2 / 18$ & ND & $1 / 18$ \\
\hline Huang [5] & 38 & $60.4 \pm 17.6$ & 76.3 & $1.8 \pm 1.6$ & ND & ND & ND \\
\hline Antopolsky [6] & 38 & 51.7 & 48.3 & 0.86 & $3 / 38$ & ND & ND \\
\hline Rhee [17] & 67 & $56.1 \pm 16.4$ & 52.2 & $1.65 \pm 0.42$ & $27 / 67$ & 40.6 & $1 / 67$ \\
\hline Bourgault [18] & 94 & $52.9 \pm 16.6$ & 61 & ND & $38 / 94$ & ND & $7 / 94$ \\
\hline Bae [19] & 100 & $59 \pm 17$ & ND & $1.16 \pm 0.68$ & $30 / 100$ & ND & $17 / 100$ \\
\hline Caravaca-Fontán [20] & 62 & $67 \pm 18$ & 48 & $1.44 \pm 0.71$ & $35 / 62$ & 6 & $14 / 62$ \\
\hline Oh [1] & 438 & 60 (17-97) & 58.2 & $0.95(0.35-5.60)$ & $88 / 438$ & ND & ND \\
\hline García-García [this study] & 59 & $63(30-93)$ & 59.3 & 1.52 & $27 / 59$ & 37.7 & $3 / 59$ \\
\hline
\end{tabular}

Adapted from Rhee et al. [17]. ND, no data available.

In our study, $30-50 \%$ of the patients with renal infarction had no provoking factor, and these data are similar to those published in other case series $[5,6]$. A previous study found that patients with idiopathic renal infarction had a mean age $<40$ years, while patients with a cardioembolic etiology had a mean age of 60 years [3]. In our study, the group of patients with provoked renal infarction was formed mainly by those with atrial fibrillation (30 patients), renal artery malformation (4 patients), and antiphospholipid syndrome (1 patient). These patients were significantly older than those with idiopathic renal infarction (69.9 vs. 57.9 years).

A thrombophilia study was performed on $22 \%$ of the patients in our sample, although the study of hereditary thrombophilia in patients with arterial thrombosis is discouraged due to its scarce relationship to these events [9-11]. In our series, 1 patient was diagnosed with a major thrombophilia (antiphospholipid syndrome), and in another 4 patients, hyperhomocysteinemia was detected, whose relationship to arterial thrombosis is not demonstrated [12, 13]. Therefore, and in the absence of guidelines for the management of patients with renal infarction, a complete thrombophilia study (including genetic defects and levels of homocysteine, proteins $C$ and $S$, and antithrombin) would not be indicated for these patients, and the study of antiphospholipid syndrome should only be considered in selected patients, mainly those in which there is no cardioembolic condition and the arteriosclerotic load is low.

Evidence concerning the clinical presentation, outcomes, and management of patients with acute renal infarction is limited, and it is fundamentally based on case series with a moderate number of patients $[1,4,7,14-21]$. There is a significant discrepancy regarding the baseline characteristics presented in the published case series: the mean age ranges between 44 and 69 years; likewise, the incidence of acute renal failure and the follow-up periods are markedly different [14-21]. Table 4 summarizes the main case series in the recent literature. The patients with idiopathic renal infarction in our series were younger, as has already been described in other series [4, 20]; however, there is also a discrepancy in this point, where other series describe a more advanced age for patients with idiopathic renal infarction [18].

This discrepancy may be due to differences in the classification of "idiopathic" between the different case series. In this sense, some authors classify as idiopathic renal infarction patients those without overt cardiac pathology $[4,20]$, while other authors included into the 


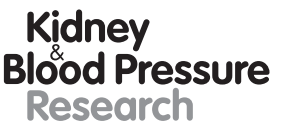

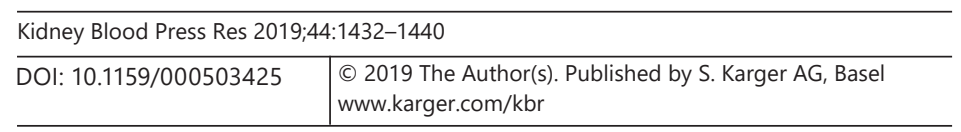

García-García et al.: Idiopathic versus Provoked Renal Infarction

"provoked" category those patients with hereditary thrombophilias or hyperhomocysteinemia, which, as already mentioned, have little or no impact on the pathogenesis of arterial infarction $[1,18,21]$. These differences in classification between the different studies limit the extraction of conclusions, although we can affirm that there is a significant percentage of patients for whom the etiology of their renal infarction remains unclear.

During the follow-up of our patients, renal impairment was detected in $50 \%$ of the patients, but only $6.5 \%$ developed severe renal impairment due to renal infarction, a rate similar to those found in other series [15, 17, 20-23]. A Japanese study found that in patients with acute renal infarction, the GFR was reduced by around $30 \%$, and then it gradually recovered to around $80 \%$ of the original value after 1 year of follow-up [22]. We did not find any differences between the incidence of renal failure at diagnosis and at follow-up at 6 months, as described in the most extensive series published in this regard [1]. Interestingly, the incidence of recurrence of arterial thrombosis was significantly lower in the group of patients with idiopathic renal infarction. This has not been mentioned in most of the published series [17, 18, 21], while Oh et al. [1] and Caravaca-Fontán et al. [20] did not find significant differences in terms of arterial recurrence between the different groups - even though, as already mentioned, the classification of the patients was done differently in the various studies mentioned.

Our study presents one of the longest follow-ups of patients with acute renal infarction described in the literature, although it has some limitations. Firstly, while the sample size allows expanding our knowledge about this pathology, the conclusions drawn are limited because it was a single-center study. Secondly, since it was a retrospective study, patient management was carried out at the discretion of the doctor in each case, which could have had an impact on the outcomes of each patient.

In conclusion, renal infarction is mainly associated with atrial fibrillation in more than half of the patients, and to a lesser extent with renal artery malformations and hypercoagulable states. However, in a significant number of cases the etiology of renal infarction remains unclear, these patients being younger and having fewer recurrences of arterial thrombosis during follow-up. Clinical follow-up is essential, including an evaluation for thrombosis recurrence. Tests to rule out cardioembolic arrhythmias, including ECG and Holter ECG, should be performed in all cases, and periodic reevaluations of these tests should be considered in patients with unprovoked renal infarction. Thrombophilia testing is not routinely recommended, and only selected patients should be tested for antiphospholipid syndrome.

\section{Statement of Ethics}

This paper adheres to the actual regulations of the Spanish medical system. The authors have no ethical conflicts to disclose. This study protocol has been approved by the hospital's research committee. Patient consent was not necessary for this type of study.

\section{Disclosure Statement}

The authors have no conflicts of interest to declare.

\section{Funding Sources}

This research did not receive any specific grant from funding agencies in the public, commercial, or not-for-profit sectors. 


\section{References}

1 Oh YK, Yang CW, Kim YL, Kang SW, Park CW, Kim YS, et al. Clinical characteristics and outcomes of renal infarction. Am J Kidney Dis. 2016 Feb;67(2):243-50.

2 Hoxie HJ, Coggin CB. Renal Infarction: statistical study of two hundred and five cases and detailed report of an unusual case. Arch Intern Med (Chic). 1940;65(3):587-94.

3 Domanovits H, Paulis M, Nikfardjam M, Meron G, Kürkciyan I, Bankier AA, et al. Acute renal infarction. Clinical characteristics of 17 patients. Medicine (Baltimore). 1999 Nov; 78(6):386-94.

4 Bolderman R, Oyen R, Verrijcken A, Knockaert D, Vanderschueren S. Idiopathic renal infarction. Am J Med. 2006 Apr;119(4):356.e9-12.

5 Huang CC, Lo HC, Huang HH, Kao WF, Yen DH, Wang LM, et al. ED presentations of acute renal infarction. Am J Emerg Med. 2007 Feb;25(2):164-9.

6 Antopolsky M, Simanovsky N, Stalnikowicz R, Salameh S, Hiller N. Renal infarction in the ED: 10-year experience and review of the literature. Am J Emerg Med. 2012 Sep;30(7):1055-60.

7 Korzets Z, Plotkin E, Bernheim J, Zissin R. The clinical spectrum of acute renal infarction. Isr Med Assoc J. 2002 Oct; 4(10):781-4.

8 Javaid MM, Butt MA, Syed Y, Carr P. Acute renal infarction: an unusual cause of abdominal pain. Ren Fail. 2009; 31(5):406-8.

9 Coppens M, van de Poel MH, Bank I, Hamulyak K, van der Meer J, Veeger NJ, et al. A prospective cohort study on the absolute incidence of venous thromboembolism and arterial cardiovascular disease in asymptomatic carriers of the prothrombin 20210A mutation. Blood. 2006 Oct;108(8):2604-7.

10 Connors JM. Thrombophilia testing and venous thrombosis. N Engl J Med. 2017 Sep;377(12):1177-87.

11 Boekholdt SM, Kramer MH. Arterial thrombosis and the role of thrombophilia. Semin Thromb Hemost. 2007 Sep;33(6):588-96.

12 Kim RJ, Becker RC. Association between factor V Leiden, prothrombin G20210A, and methylenetetrahydrofolate reductase $\mathrm{C677T}$ mutations and events of the arterial circulatory system: a meta-analysis of published studies. Am Heart J. 2003 Dec;146(6):948-57.

13 Eldibany MM, Caprini JA. Hyperhomocysteinemia and thrombosis: an overview. Arch Pathol Lab Med. 2007 Jun;131(6):872-84.

14 Lessman RK, Johnson SF, Coburn JW, Kaufman JJ. Renal artery embolism: clinical features and long-term follow-up of 17 cases. Ann Intern Med. 1978 Oct;89(4):477-82.

15 Hazanov N, Somin M, Attali M, Beilinson N, Thaler M, Mouallem M, et al. Acute renal embolism. Forty-four cases of renal infarction in patients with atrial fibrillation. Medicine (Baltimore). 2004 Sep;83(5):292-9.

16 Tsai SH, Chu SJ, Chen SJ, Fan YM, Chang WC, Wu CP, et al. Acute renal infarction: a 10-year experience. Int J Clin Pract. 2007 Jan;61(1):62-7.

17 Rhee H, Song SH, Won Lee D, Lee SB, Kwak IS, Seong EY. The significance of clinical features in the prognosis of acute renal infarction: single center experience. Clin Exp Nephrol. 2012 Aug;16(4):611-6.

18 Bourgault M, Grimbert P, Verret C, Pourrat J, Herody M, Halimi JM, et al. Acute renal infarction: a case series. Clin J Am Soc Nephrol. 2013 Mar;8(3):392-8.

19 Bae EJ, Hwang K, Jang HN, Kim MJ, Jeon DH, Kim HJ, et al. A retrospective study of short- and long-term effects on renal function after acute renal infarction. Ren Fail. 2014 Oct;36(9):1385-9.

20 Caravaca-Fontán F, Pampa Saico S, Elías Triviño S, Galeano Álvarez C, Gomis Couto A, Pecharromán de las Heras I, et al. Acute renal infarction: clinical characteristics and prognostic factors. Nefrologia. 2016;36(2): 141-8.

21 Lin WL, Seak CJ, Wu JY, Weng YM, Chen HC. Risk factors for development of chronic kidney disease following renal infarction: retrospective evaluation of emergency room patients from a single center. PLoS One. 2014 Jun;9(6):e98880.

22 Nagasawa T, Matsuda K, Takeuchi Y, Fukami H, Sato H, Saito A, et al. A case series of acute renal infarction at a single center in Japan. Clin Exp Nephrol. 2016 Jun;20(3):411-5.

23 Yousuf T, Ziffra J, Iqbal H, Said A, Oyama JH, Lerma EV, et al. Two cases of acute renal infarction in the setting of atrial fibrillation. Ochsner J. 2016;16(3):312-4. 